\title{
Reversal of childhood idiopathic scoliosis in an adult, without surgery: a case report and literature review William J Brooks ${ }^{1}$, Elizabeth A Krupinski ${ }^{2}$ and Martha C Hawes*3
} Address: ${ }^{1}$ Restorative Care Foundation, Kansas City, MO 64152, USA, ${ }^{2}$ Department of Radiology, University of Arizona, Tucson AZ 85724, USA
and ${ }^{3}$ Division of Plant Pathology and Microbiology, School of Plant Sciences, University of Arizona, Tucson AZ 85721, USA

Email: William J Brooks - wjbdo@wjbrooksdo.com; Elizabeth A Krupinski - krupinski@radiology.arizona.edu; Martha C Hawes* - mhawes@u.arizona.edu

* Corresponding author

Published: 15 December 2009

Scoliosis 2009, 4:27 doi:10.1/86/1748-7/61-4-27
Received: 10 February 2009

Accepted: 15 December 2009

This article is available from: http://www.scoliosisjournal.com/content/4/I/27

(C) 2009 Brooks et al; licensee BioMed Central Ltd.

This is an Open Access article distributed under the terms of the Creative Commons Attribution License (http://creativecommons.org/licenses/by/2.0), which permits unrestricted use, distribution, and reproduction in any medium, provided the original work is properly cited.

\begin{abstract}
Background: Some patients with mild or moderate thoracic scoliosis (Cobb angle $<50-60$ degrees) suffer disproportionate impairment of pulmonary function associated with deformities in the sagittal plane and reduced flexibility of the spine and chest cage. Long-term improvement in the clinical signs and symptoms of childhood onset scoliosis in an adult, without surgical intervention, has not been documented previously.
\end{abstract}

Case presentation: A diagnosis of thoracic scoliosis (Cobb angle 45 degrees) with pectus excavatum and thoracic hypokyphosis in a female patient (DOB 9/17/52) was made in June 1964. Immediate spinal fusion was strongly recommended, but the patient elected a daily home exercise program taught during a 6-week period of training by a physical therapist. This regime was carried out through 1992, with daily aerobic exercise added in 1974. The Cobb angle of the primary thoracic curvature remained unchanged. Ongoing clinical symptoms included dyspnea at rest and recurrent respiratory infections. A period of multimodal treatment with clinical monitoring and treatment by an osteopathic physician was initiated when the patient was 40 years old. This included deep tissue massage (1992-1996); outpatient psychological therapy (1992-1993); a daily home exercise program focused on mobilization of the chest wall (1992-2005); and manipulative medicine (1994-1995, 1999-2000). Progressive improvement in chest wall excursion, increased thoracic kyphosis, and resolution of long-standing respiratory symptoms occurred concomitant with a $>10$ degree decrease in Cobb angle magnitude of the primary thoracic curvature.

Conclusion: This report documents improved chest wall function and resolution of respiratory symptoms in response to nonsurgical approaches in an adult female, diagnosed at age eleven years with idiopathic scoliosis.

\section{Background}

Respiratory function within populations of patients with thoracic scoliosis, in general, is inversely correlated with curvature magnitude, with increasing impairment as Cobb angle increases [1-6]. However, substantial varia- tion occurs among individual patients. At one extreme, cardiopulmonary disease secondary to idiopathic scoliosis (IS) has been reported to cause sudden death in young adults with 60 - to 70 -degree curves $[7,8]$. Other patients with similar curves may exhibit normal pulmonary func- 
tion (PF) [5,9-12]. PF in patients with mild or moderate curves ( $<60$ degrees) can range from normal to significantly impaired [5,11-22]. Thoracic kyphosis, normally ranging between 25-50 degrees, is reduced in some individuals ("hypo-kyphosis"), and this sagittal plane deformity together with reduced flexibility of the spine and thoracic cage may exacerbate pulmonary dysfunction $[1,10,14,23-25]$. Pectus excavatum, a depression of the sternum, is present in many scoliosis patients, and this condition by itself can contribute to PF deficiencies [2628].

Even in patients without measurable impairment of VC in basal static conditions, reduced PF is often revealed during exercise tests [19,29-32]. A significant negative correlation has been shown between exercise capacity and Cobb angle from 10 degrees to 70 degrees in adolescent IS (AIS) patients [2]. Exercise capacity among a group of AIS patients with an average curve of 32.8 degrees and VC within normal limits was significantly reduced in comparison with a control group of subjects without spinal deformities [30]. The long-term impact of these impairments in scoliosis patients has not been examined, to date. However, in the general population, reduced VC and reduced exercise capacity are independent predictors of increased mortality [33-36]. Among 6213 men followed for 6.2 years, peak exercise capacity was a stronger predictor of early death than hypertension, smoking, and diabetes [36].

Impaired chest expansion resulting from chest wall deformity, rather than lack of physical activity or altered muscle tone, is thought to underlie reduced PF among patients with IS [1,37-42]. Evidence in support of this hypothesis includes the observation that PF defects characteristic of thoracic scoliosis can be induced in normal patients by immobilizing chest cage function with tape or corsets $[43,44]$. Conversely, PF improves in response to mobilization exercises designed to increase chest expansion [45]. Yet little information regarding long-term effects of impaired chest expansion in scoliosis patients is available. Among 195 AIS patients, evaluated at an average age of 42 years, chest expansion of $<3.8 \mathrm{~cm}$ was found to be correlated with significantly reduced VC, recurrent respiratory infection, and shortness of breath [46]. Among a subset of this population of AIS patients evaluated after age $>54$ years $(n=57), 58 \%$ had chest expansion reduced to $<2 \mathrm{~cm}$, but PF was not measured [47]. However, in a separate study, among subjects in the general population $(n=48)$ evaluated at $>54$ years of age, only $15 \%$ had chest expansion reduced to $<2 \mathrm{~cm}[48]$.

Patients with moderate to severe scoliosis diagnosed before puberty and present at skeletal maturity are at risk of curvature progression throughout life [46,49-52]. As a result of this increasing curvature, together with the normal effects of aging, women with scoliosis experience progressive loss in height beginning in early adulthood $[53,54]$.

A previous study documented increased chest excursion and resolution of long-standing pulmonary symptoms in the subject of this case report [55]. The current report documents that, from ages 40-53 years, height increased by 2 $\mathrm{cm}$, thoracic hypokyphosis improved, and the Cobb magnitude of the patient's longstanding thoracic curve was reduced. A preliminary report was presented at the May 2002 meeting of the International Research Society for Spinal Deformity in Athens, Greece [56].

\section{Case presentation}

The patient $(\mathrm{MCH})$ is a female born $9 / 17 / 1952$, the third of five children. Prenatal bleeding developed in the first trimester, and delivery (at full term) was breech and complicated by anoxia. Early development was normal, but a right inguinal herniorrhaphy was performed on $1 / 3$ / 1959. By age 6.5 years an asymmetric posture [57] was apparent in casual photographs (Figure 1A). After puberty a marked torso deformity was evident (Figure 1B). From childhood through 1992 (age 40 years), symptoms included dyspnea at rest, increasing in severity and associated with nausea upon mild exertion or at high altitude. Recurrent respiratory infections with fever and deep chest cough (3-5 episodes per year, each lasting 3-10 weeks) also were present. The patient lived in a rural area, never suffered from asthma, never smoked, and avoided proximity to smokers due to sensitivity to secondhand smoke. No seasonal allergies were present during childhood and
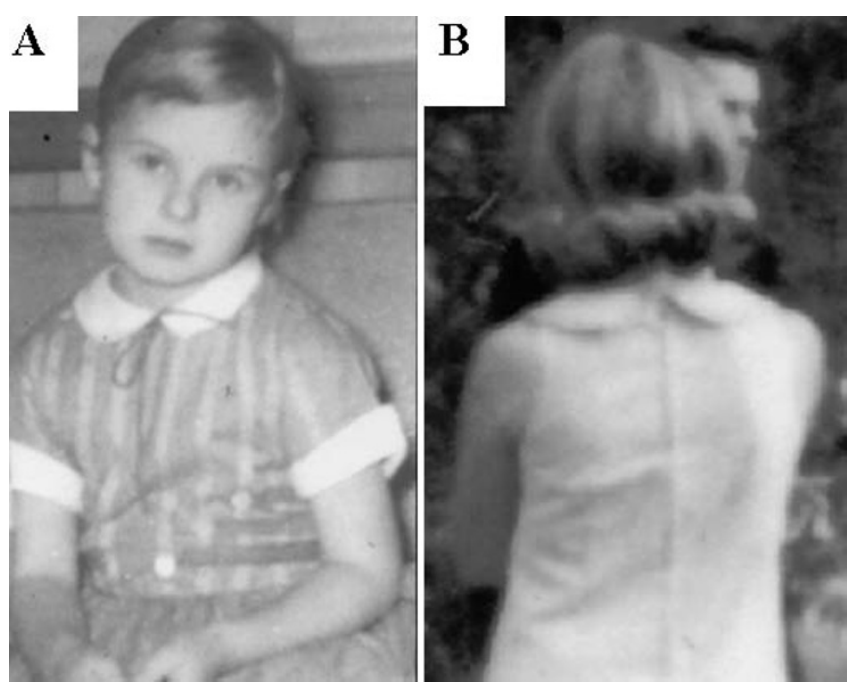

Figure I

Postural deformity as seen in casual photographs (A) age 6 years; and (B) age 16 years. 
early adulthood. No pulmonary function tests were prescribed by treating physicians during this period. During childhood daily activities included participation in marching band, swimming, horseback riding and other farm chores but recurrent vertigo precluded gymnastics and other formal sports.

At age 11.7 years (pre-menarche), the patient was seen by her pediatrician in response to obvious torso deformity identified by an older sibling while horseback riding. There was no family history of scoliosis or other spinal deformities. Referral was made to an orthopedic surgeon (J. Stiles, Owensboro Daviess County Hospital, Owensboro KY, USA). The diagnosis was IS with a right thoracic Cobb angle of 45 degrees. A compensatory lumbar curve, thoracic hypo-kyphosis, and pectus excavatum were also present. Immediate spinal fusion surgery was strongly recommended but declined. Exercises taught during a 6-week period of outpatient training by a hospital resident physical therapist were prescribed as an alternative to surgery (Table 1). This program was essentially as outlined in Ponseti and Friedman [58] who described a regime of conservative treatment used in the long-term 'natural history' $[46,47]$ study of 444 patients carried out at the University of Iowa (Iowa City, IA, United States). The authors stated that "a great number of patients in this series received conservative treatment consisting of exercises designed to increase muscle strength and to correct postural imbalance. Tightness of the abdominal muscles at the side of the overhang was corrected by passive and active stretching. The patients were taught to shift their thorax into proper alignment with the pelvis" ([58], p. 381).

These exercises, in the current case, included sit-ups, sideto-side toe-touches, push-ups, 'bicycle' leg lifts, and straight leg raises (15-20 reps daily), plus side-bending and stretching in combination. Four recommended exercises were discontinued: (1) Hanging by the arms from a bar triggered immediate pain in the right inguinal region (where scar tissue from herniorrhaphy was present) and lower back, with loss of sensation in the right foot; (2) a posture exercise in which the back was flattened repeatedly against a wall triggered neck pain; (3) assisted neck stretches, which required the patient to bend her head to the side facilitated by a partner (parent), also were discontinued due to increased pain; (4) back bends from a prone position were discontinued when the supervising physical therapist noticed exacerbation of the torso asymmetry within 2-3 weeks of daily replication. The other exercises were included in a 30-40 minute regime carried out daily from 1964-1974. In 1974, in response to increased dyspnea while living at high altitude, a 30-40 min aerobic exercise routine was added to the daily routine and maintained through 1992. Depending on circumstances, this included a daily 10-mile round-trip hike to work, a 16-mile round trip bicycle ride to work, or a 2-mile jog at a local track. Yoga headstands and kicks also were added. Dyspnea persisted as a symptom despite these activities.

Deep tissue whole body massage was carried out monthly from June-December 1991 by a licensed massage therapist (C. Kotch, Tucson AZ, USA) in response to neck pain; fourteen additional sessions were carried out from December 1992-February 1996. The primary focus of treatment was mobilization of the right psoas, adhesions surrounding right inguinal scar tissue, chest wall rigidity and limited cervical spine range of motion. In February 1992 outpatient individual psychological therapy was initiated in response to psychological decompensation concurrent with intense multi-regional pain [55]. Daily strengthening and aerobic exercises were discontinued at this time and replaced with torso, abdominal and chest wall mobilization and respiratory exercises including 'loud vocalization' [59]. In April 1992 a noticeable improvement in torso appearance developed suddenly, manifested by spontaneous decrease in forward rotation

Table I: Outline of exercises and treatments, 1964-2005

\begin{tabular}{|c|c|}
\hline Year & Exercises and Treatments \\
\hline 1964-1974: & Prescribed calisthenics, stretching, walking ( $\geq 30$ minutes daily) \\
\hline 1974-|99|: & Calisthenics, stretching, plus aerobics (biking, jogging) (60 min daily) \\
\hline 1991: & Deep tissue massage therapy (monthly 60-minute sessions, June-December) \\
\hline \multirow[t]{4}{*}{ |992-200|: } & Daily home mobilization exercises (no strengthening or aerobic exercise) \\
\hline & Outpatient psychological therapy $(1992,1993)$ \\
\hline & Deep tissue massage therapy (fourteen 60 -minute sessions) \\
\hline & CMM (four sessions in 1994-1995; seven sessions in 1999-2000) \\
\hline \multirow[t]{2}{*}{ 200I-2005: } & Daily mobilization, strengthening, and aerobic exercise (40-50 min daily) \\
\hline & Incentive spirometry (5 reps daily) \\
\hline
\end{tabular}


of the right shoulder (Figure 1). This occurred in correlation with increased ability to turn the head to the side, decreased discomfort and a sensation of improved breathing.

In February 1993 the patient $(\mathrm{MCH})$ initiated a collaboration with the first author (WJB, Faculty of Medicine, University of Arizona), for a study designed to evaluate and document any changes in signs and symptoms (e.g. respiratory function, chest wall morphology and excursion, Cobb angle). In addition, intervention in the form of comprehensive manipulative medicine (CMM) was carried out four times during 1994-1995 and on seven occasions during 1999-2000 [55,60]. This approach to the use of manipulative techniques significantly differs diagnostically from methods that employ spinal mis-alignment, postural imbalance, asymmetrical active range of motion, and/or asymmetrical passive range of motion as sufficient markers of musculoskeletal dysfunction [e.g. [61]]. CMM refers to the use of a broad spectrum of (in this case, direct action) manipulative medicine techniques employed for the purpose of restoring optimal available motion to the entire musculoskeletal system, including the cranium, as described $[55,60]$. A daily 40 - to 60-min home mobilization exercise program (1993-2005) included sustained pressure applied to painful muscle spasms, isometric chest stretches (palms pressed together while expanding the rib cage), and manual traction using a home gym [56]. Incentive spirometry was added in 2001. Aerobic and strengthening exercise (sit-ups, abdominal crunches, bicycle, hiking, jogging, side kicks, weight lifting, etc) was reincorporated into the daily regime in 2001. Body weight was stable at $62 \pm 3 \mathrm{~kg}$.

\section{Measurement of Chest Expansion, Torso Deformity, and Cobb Angle}

The chest excursion and hemi-thorax size measurements were performed with a cloth tape measure referencing specific bony landmarks $[48,55,62]$. Hemi-thorax size is the circumferential distance around the hemi-thorax at maximum exhalation and maximum inhalation, and is expressed as mean and standard error of 30 replicates taken over a 2-day period. Measurement of height was carried out in the morning. Rib prominence measurements, given as mean and standard error of at least 10 replicates over a 3-day period, were based on the Adams forward bending test using a Bunnell scoliometer [63]. Intra-thoracic diameter was measured from lateral films, using a ruler placed between the anterior body of the T-7 vertebra and the posterior face of the sternum. Vertebral rotation was estimated according to the method of Nash and Moe [64].

To our knowledge, variability in Cobb angle measurement in aging adults has not been evaluated systematically. However, substantial inter-rater and interdisciplinary variability in Cobb angle measurement has been documented, especially in secondary curves and in cases where different end-points are selected for curvature classification [65-70]. Therefore Cobb measurement was done by two methods, a double blind study by radiologists at the treating institution (Method 1), and nonblinded readings by two scoliosis specialists at independent institutions (Method 2). All standing anterior-posterior (AP) radiographs and sagittal radiographs were made at the same facility by the same technician (W. Quirk, Senior Radiology Technician, University Medical Center, Tucson AZ), and were taken at maximum inhalation with the same instructions to the patient: "Stand up straight, take a deep breath, and hold." To provide blinded Cobb angle readings, as described by Goldberg et al. [66], the second author removed from the films all identifying information and any markings from previous measurements. An identifying number then was assigned arbitrarily to each set of radiographs taken at four-year intervals. Three readers, none of whom had seen the films previously or were known by the patient or the first author, were given the same set of films in random order. All three readers are board-certified by the American Board of Radiology, http://theabr.org/ and employed in The University of Arizona College of Medicine, Department of Radiology, Tucson AZ. Each recorded three readings for each film. Repeated measures analysis of variance was used to evaluate statistical significance of mean difference.

\section{Results}

Increase in height

The patient's height increased by $2 \mathrm{~cm}$ between 1990 (65.70 inches; $167.64 \mathrm{~cm}$ ) and 2005 (66.5 inches; 169.67 $\mathrm{cm})$.

\section{Improved pulmonary symptoms}

Vital capacity in 1996, 2001, and 2005, respectively, was 1.6 liters (71\% predicted), 3.97 liters (115\% predicted), and 3.99. Relief from respiratory symptoms including dyspnea and recurrent respiratory infection, as reported previously [55], was maintained.

\section{Improvement in torso symmetry}

In 1992 , there was a $12 \pm 2 \mathrm{~cm}$ difference between the left and right hemi-thorax at maximum inhalation, and a 10 $\pm 1 \mathrm{~cm}$ difference at maximum exhalation; by 2005 , these differences were reduced to $2 \pm 2 \mathrm{~cm}$ and $1 \pm 1 \mathrm{~cm}$, respectively (Figure 2). The rib prominence [61] was reduced from $18 \pm 3$ to $11 \pm 2$ degrees.

\section{Increase in sagittal plane Cobb magnitude}

The Cobb angle of the sagittal thoracic curvature increased from $17 \pm 2$ degrees in 2001 (Figure $3 \mathrm{~A}$ ) to $33 \pm 3$ degrees in 2005 (Figure 3B). During the same period, the AP intrathoracic diameter during maximum inhalation, as meas- 

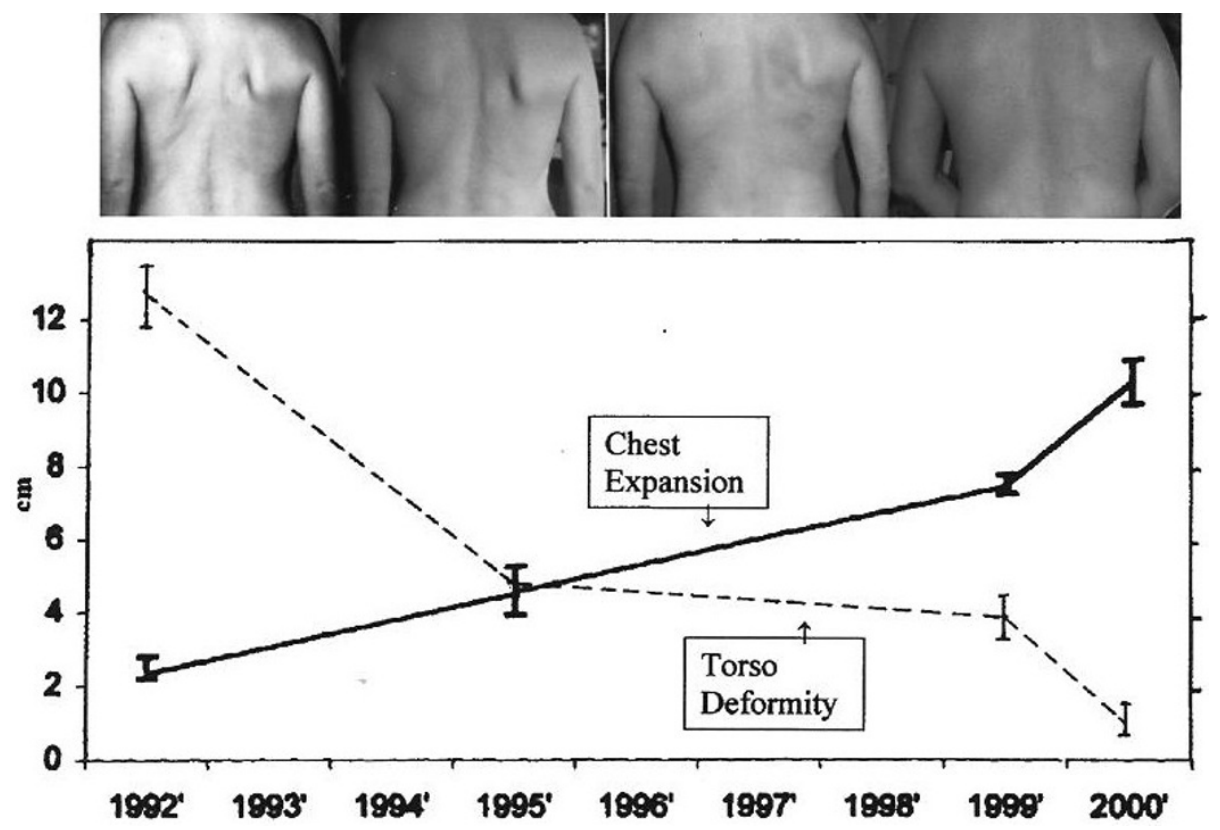

Figure 2

Improved chest wall morphology and function. Top: Clinical aspect of the deformity documented with photography. Photos (left to right) were taken in 1991, 1995, 1999, and 2002, respectively. Bottom: Inverse relationship between increased chest expansion (solid line) and reduced torso deformity (broken line). 'Chest expansion' (cm) was measured directly based on the difference in total chest circumference at minimum and maximum inhalation [48,62]; 'torso deformity' values (cm) reflect the difference between right and left hemi-thorax, at maximum inhalation. Each value represents mean and standard deviation from at least 30 measurements taken over a 48-h period, measured at intervals between I99। (patient age: 39 years) through 2005 (patient age: 53 years, 2.I years post-menopause).

ured directly on a sagittal radiograph, increased from 8.0 $\mathrm{cm}$ (Figure 3A, white arrows) to $10.5 \mathrm{~cm}$ (Figure 3B, black arrows).

\section{Decrease in coronal plane Cobb magnitude}

From 1990 (Figure 4A) through 2005 (Figure 4B) the magnitude of Cobb angle for the primary thoracic curve declined by $>10$ degrees (Table 2 ). Grade I-II rotation of each apical vertebra was present [64].

\section{Discussion}

The negative impact of thoracic spinal deformity on respiratory function was recognized and described in ancient times by Hippocrates $[1,59]$. Current studies among children and adults with thoracic scoliosis whose Cobb angle ranged from 30-80 degrees have revealed measurable pulmonary deficits manifested as impaired vital capacity, reduced exercise capacity, cardiac hypertrophy and symptoms including dyspnea and recurrent respiratory infections [1-25,29-42,46]. Yet in recent years some spine surgeons have argued that, with the exception of cases diagnosed before the age of five years and with a Cobb angle of $>100$ degrees, IS patients suffer from 'no functional limitations' and that, moreover, the improvement of 'appearance and deformity with all its social and psychological deprivation is the only indication for treatment' [71]. The stated goal of such treatment is 'to restore acceptability and help mitigate future social and psychological disadvantage' [72], not to restore or maintain health and function. Even routine PF testing for scoliosis patients prior to surgery is described as 'controversial' [73]. As long ago as 1964, however, Mankin and coauthors [21] noted, "Most physicians think that IS is a 'cosmetic' problem and that its major effect is to deform an individual with no harm to the internal organs. It is apparent from this study that appreciable pulmonary deficits do occur but are easily detected by simple spirometry. " Chest cage rigidity, which may contribute to PF deficits in scoliosis patients, increases with age, could in part account for the observation that respiratory failure can occur in adult IS patients even when there is no progression of the curvature $[74,75]$. The possibility that undiagnosed PF deficits contribute to psychological distress found to be prevalent among juvenile, adolescent, and adult IS patients, remains unexplored [76-80].

In patients who undergo spinal fusion surgery, VC does not improve in correlation with improved Cobb angle [1,9-12], and among surgery followup studies published since 1941 the impact of spinal fusion on chest excursion has never been included as an outcome measure [81]. By 

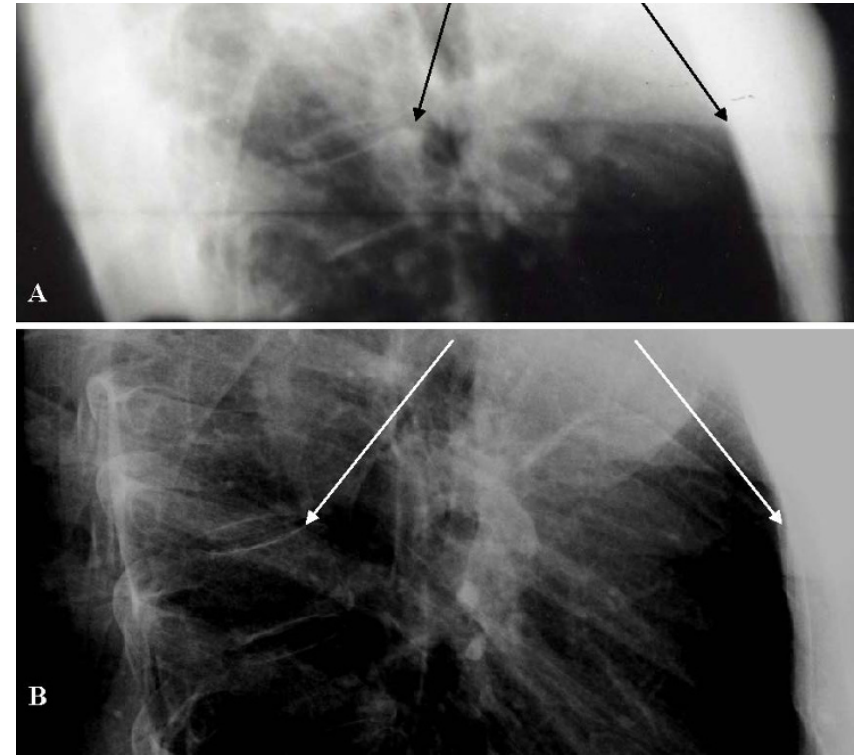

Figure 3

Increased sagittal plane curvature. Lateral radiographs of the thoracic spine, were taken in (A) 200I; and (B) 2005. Arrows indicate the anterior edge of T7 (left) and a bony landmark on the posterior edge of the sternum (right). Radiographs were taken by the same technician, with the patient in a standing position, at maximum inhalation, using the same machine (University Medical Center, Tucson AZ).

contrast, significantly improved VC and increased chest expansion occurred in several hundred scoliosis patients within four weeks in response to an inpatient physiotherapeutic approach $[45,82]$. This approach now has been

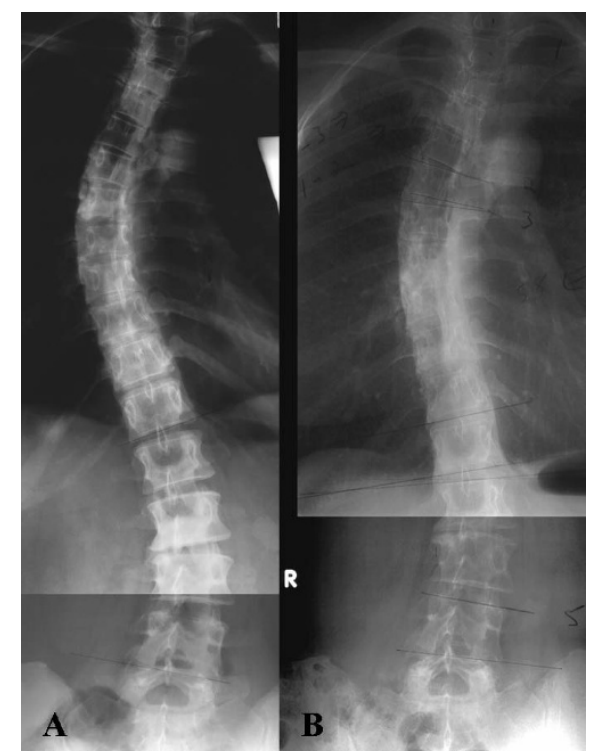

Figure 4

AP standing radiographs in (A) 1990 and (B) 2005.
Table 2: Cobb magnitude measurements, 1990-2005'

\begin{tabular}{|c|c|c|c|c|c|}
\hline Vertebrae & 1990 & 1994 & 1998 & 2001 & 2005 \\
\hline \multicolumn{6}{|l|}{ Method \#I } \\
\hline T4-TI2 & $47 \pm 2$ & $38 \pm 2$ & $34 \pm I$ & $28 \pm 2$ & $24 \pm 2$ \\
\hline LI-L4 & $26 \pm 1$ & $19 \pm 2$ & $17 \pm 1$ & $13 \pm 1$ & $10 \pm 2$ \\
\hline \multicolumn{6}{|l|}{ Method \#22 } \\
\hline T4-TI I & 45 & 39 & 35 & 34 & \\
\hline T4-TIO & & & & & 33 \\
\hline TI2-L4 & 30 & 24 & 22 & 22 & \\
\hline TII-L33 & & & & & 23 \\
\hline \multicolumn{6}{|l|}{ Method \#24 } \\
\hline T4-TII & 45 & 38 & & & 34 \\
\hline T5-TII & & & 36 & & \\
\hline TI2-L4 & 27 & & & & 22 \\
\hline
\end{tabular}

IThe values for the primary thoracic curvature are provided in boldfaced type. Method \#I: values for Cobb angle represent means and standard deviation from triplicate readings by each of three readers independent of this study, according to protocols defined by Goldberg et al. [66]. Cobb magnitude mean values for the primary and secondary curvatures, in 1990, were statistically distinct from the mean values in $2005(\mathrm{p}<0.00 \mathrm{I})$. Method \#2: Two readers from independent institutions carried out non-blinded readings from film copies provided by the authors.

2 Method \#2, measurements by Reader \#1.

${ }^{3} \mathrm{~L} 2$-L3 intervertebral space narrowing and degeneration with spur formation. The character of the primary thoracic curve from 19902005 was judged to be altered, from eight included vertebrae to seven (T4 - TII to T4-TI0). The altered endpoints are provided. ${ }^{4}$ Method \#2, measurements by Reader \#2. The character of the primary thoracic curve from 1990-2005 was judged to be altered, from eight included vertebrae to seven (T4-TII to T5-TII). The altered endpoints are provided.

adapted successfully for outpatient treatment strategies $[83,84]$. Recent clinical studies reveal success in reducing pain and improving Cobb angle with exercise, manipulation, and other nonsurgical approaches in patients, including adults [85-90]. Rapid improvement of pectus excavatum severity in an adult, in correlation with individualized physical therapy, also has been documented [91]. The results from these studies, together with the current case report, indicate that despite popular beliefs [71] a reduction in clinical signs and symptoms of scoliosis that impair quality of life and function can be achieved in response to specific physical interventions. Investigations of non operative methods in the treatment of adult scoliosis are warranted [92-98]. Based on the known biologi- 
cal and biomechanical processes associated with progression of scoliosis, application of such methods can be predicted to be most effective in halting or reversing lateral and torsional deformity of the spine when employed early in the disease process $[99,100]$. School screening programs have been found to be an effective method to detect and diagnose scoliosis in its earlier stages, and can play a key role in such research [101].

\section{Conclusions}

Stable improvement in chest wall symmetry and resolution of long-standing respiratory symptoms in an adult with pectus excavatum, thoracic scoliosis and hypokyphosis, has not previously been reported. Improvement in magnitude of Cobb angle occurred in parallel with the observed changes in function.

\section{Competing interests}

The authors declare that they have no competing interests.

\section{Authors' contributions}

$\mathrm{MCH}, \mathrm{EAK}$, and WJB each participated in the design and writing of this manuscript. EAK recruited the team of experts for Cobb angle readings of serial followup radiographs at the treating institution, supervised the blinded measurement process, and carried out statistical analysis of the data. MCH (the patient in this case report) carried out the literature search. All authors read and approved the final manuscript.

\section{Consent}

Informed consent was obtained from the patient for publication of this case report and accompanying images. A copy of the written consent is available for review by the Editor-in-Chief of this journal.

\section{Acknowledgements}

The authors wish to thank Michael M. Patterson, Ph.D. (Nova Southeastern University College of Osteopathic Medicine, United States), and Don Speer, M.D. (University Arizona College of Medicine, Tucson AZ, United States), and Tomasz Kotwicki, M.D. (University of Medical Sciences, Poznan, Poland) for contributions in manuscript writing; the radiologists of University Arizona College of Medicine (Tucson, AZ, United States); and Drs. T.B. Grivas (Orthopaedic Department, Thriasio General Hospital, Attica, Greece) and M. Rigo (Instituto Èlena Salvá. Barcelona Spain), for reading the films; and Jeb Zirato (Chief Medical Photographer, University of Arizona College of Medicine, Tucson AZ, United States) for preparation of the x-ray photography.

\section{References}

I. Bowen RM: Respiratory management in scoliosis. In Moe's Textbook of Scoliosis and Other Spinal Deformities 3rd edition. Edited by: Lonstein J, Bradford D, Winter R, Ogilvie J. Philadelphia: WB Saunders; 1995:572-580.

2. Chong KC, Letts RM, Cumming GR: Influence of spinal curvature on exercise capacity. J Ped Orth I 98I, I:25I-254.

3. Flagstad AE, Kollman S: Vital capacity and muscle study in one hundred patients with scoliosis. J Bone Jt Surg 1928, 10:724-734.
4. Gagnon S, Jodoin A, Martin R: Pulmonary function test study and after spinal fusion in young IS. Spine 1989, 5:486-490.

5. Szeinberg A, Canny GJ, Rashed N, Giuseppina V, Levison H: Forced VC and maximal respiratory pressures in patients with mild and moderate scoliosis. Ped Pulmonol 1988, 4:8-12.

6. Wong CA, Cole AA, Watson L, Webb J, Johnston I, Kinnear WJM: Pulmonary function before and after anterior spinal surgery in adult idiopathic scoliosis. Thorax 1996, 52:534-536.

7. Hitosugi M, Shigeta A, Takatsu A: An autopsy case of sudden death in a patient with IS. Medicine Science and the Law 2000, 40:175- 178

8. Satoh F, Fujita MQ, Seto Y, Tsuboi A, Takeichi S: Sudden death in a patient with idiopathic scoliosis. J Clin Forensic Med 2006, 13:335-8.

9. Lenke LG, White DK, Kemp JS, Bridwell KH, Blanke KM, Engsberg JR Evaluation of ventilatory efficiency during exercise in patients with IS undergoing spinal fusion. Spine 2002, 27:204I-2042.

10. Newton PO, Faro FD, Gollogly S, Betz RR, Lenke LG, Lowe TG: Results of preoperative pulmonary function testing of adolescents with idiopathic scoliosis. A study of six hundred and thirty-one patients. J Bone \& Joint Surg 2005, 87 A: I 937-1946.

II. Upadhyay SS, Ho EKW, Gunawardene WMS, Leong JCY, Hsu LCS Changes in residual volume relative to $\mathrm{VC}$ and total lung capacity after arthrodesis of the spine in patients with AIS. Bone Jt Surg 1993, 75-A:46-52.

12. Vedantam $\mathrm{R}$, Crawford $\mathrm{AH}$ : The role of preoperative pulmonary function tests in patients with AIS undergoing posterior spinal fusion. Spine 1997, 22:273I-2734.

13. Weber B, Smith JP, Briscoe WA, Friedman SA, King TKC: Pulmonary function in asymptomatic adolescents with IS. Am Rev Resp Dis 1975, II I:389-397.

14. Winter RB, Lovell WW, Moe JH: Excessive thoracic lordosis and loss of pulmonary function in patients with IS. J Bone Jt Surg 198I, 57-A:972-977.

15. Cooper DM, Rojas JV, Mellins RB, Keim HA, Mansell A: Respiratory mechanics in adolescents with IS. Am Rev Resp Dis 1984, 130:16-22.

16. DiRocco PJ, Vaccaro P: Cardiopulmonary functioning in adolescent patients with mild is. Arch Phys Med Rehabil 1988, 69:198-201.

17. Gazioglu K, Goldstein LA, Femi-Pearse D, Yu PN: Study of respiratory function in IS: Comparative evaluation before and after orthopedic correction of the curvature. J Bone Jt Surg 1968, 50A:1391-1399.

18. Kearon C, Viviani GR, Killian KJ: Factors influencing work capacity in thoracic AIS. Am Rev Respir Dis 1993, 148:295-303.

19. Kesten S, Garfinkel SK, Wright T, Rebuck AS: Impaired exercise capacity in adults with moderate scoliosis. Chest I991, 99:663-666.

20. Kinnear WJM, Kinnear GC, Watson L, Web JK, Johnston ID: Pulmonary function after spinal surgery for IS. Spine 1992, 17:708-7/3.

21. Mankin HJ, Graham JJ, Schack J: Cardiopulmonary function in mild and moderate IS. J Bone Jt Surg 1964, 46-A:53-62.

22. Smyth RJ, Chapman KR, Wright TA, Crawford JS, Rebuck AS: Pulmonary function in adolescents with mild IS. Thorax 1984, 39:901-904.

23. Chun EM, Suh SW, Modi HN, Kang EY, Hong SJ, Song HR: The change in ratio of convex and concave lung volume inadolescent idiopathic scoliosis: a 3D CT scan based cross sectional study of effect of severity of curve on convex and concave lung volumes in 99 cases. Eur Spine J 2008, 17:224-229.

24. Ogilvie JW, Schendel MJ: Calculated thoracic volume as related to parameters of scoliosis correction. Spine 1988, 13:39-42.

25. Upadhyay SS, Mullaji AB, Luk KDK, Leong JCY: Relation of spinal and thoracic cage deformities and their flexibilities with altered pulmonary functions in AIS. Spine 1995, 20:24I5-2420.

26. Akcali $Y$, Ceyran H, Hasdiraz L: Chest wall deformities. Acta Chirurgica Hungarica 1999, 38: I-3.

27. Frick SL: Scoliosis in children with anterior chest wall deformities. Chest Surg Clin N Amer 2000, 10:427-436.

28. Gurnett CA, Alaee F, Bowcock A, Kruse L, Lenke LG, Bridwell KH, Kuklo T, Luhmann SJ, Dobbs MB: Genetic linkage localizes an adolescent idiopathic scoliosis and pectus excavatum gene to chromosome 18 q. Spine 2009, 34:E94-100. 
29. Smyth RJ, Chapman KR, Wright TA, Crawford MD, Rebuck AS: Ventilatory patterns during hypoxia, hypercapnia, and exercise in adolescents with mild scoliosis. Pediatrics 1986, 77:692-697.

30. Barrios C, Perez-Encinas C, Maruenda JI, Laguia M: Significant ventilatory functional restriction in adolescents with mild or moderate scoliosis during maximal exercise tolerance test. Spine 2005, 30:1610-1615.

31. Schneerson JM: Cardiac and respiratory responses to exercise in AIS. Thorax 1980, 35:347-350.

32. Schneerson JM, Madwick R: The effect of physical training on exercise ability in AIS. Acta Orthop Scand 1979, 50:303-306.

33. Balady G]: Survival of the fittest: More evidence. New Engl ] Med 2002, 346:852-855.

34. Karlson BW, Sjolin M, Lindqvist J, Caidahl K, Herlitz J: Ten-year mortality rate in relation to observations of a bicycle exercise test in patients with a suspected or confirmed ischemic event but no or only minor myocardial damage. Am Heart J 2001, 141:977-984.

35. Mannino DM, Buist AS, Petty TL, Enright PL, Redd SC: Lung function and mortality in the U.S.: data from the First National Health and Nutrition Examination Survey followup study. Thorax 2003, 58:388-393.

36. Myers J, Prakash M, Froelicher V, Partington S, Atwood JE: Exercise capacity and mortality among men referred for exercise testing. New England J Med 2002, 346:793-80I.

37. Jones RS, Kennedy JD, Hasham F, Owen R, Taylor JF: Mechanical efficiency of the chest cage in scoliosis. Thorax 1981, 36:456-46I.

38. Leong JCY, Lu WW, Luk KDK, Karlberg EM: Kinematics of the chest cage and spine during breathing in healthy individuals and in patients with AIS. Spine 1999, 24:1310-1319.

39. Lin MC, Liaw MY, Chen WJ, Cheng PT, Wong AM, Chiou WK: Pulmonary function and spinal characteristics: their relationships in persons with IS and postpoliomyelitic scoliosis. Arch Phys Med Rehab 200I, 82:335-34I.

40. Fraser RS, Müller NL, Colman N, Paré PD: The Chest Wall. In Fraser and Paré's Diagnosis of Diseases of the Chest Fourth edition. W.B. Saunders Company, Philadelphia; 1999:3019-3042.

41. George RB, Light RW, Matthay MA, Matthay RA: Chest Medicine: Essentials of Pulmonary and Critical Care Medicine. Third edition. Williams and Wilkins, Baltimore; 1995.

42. Murray JF, Nadel JA: Textbook of Respiratory Medicine. Third edition. Philadelphia PA, WB Saunders; 2000.

43. Caro CG, Butler J, DuBois AB: Some effects of restriction of chest cage expansion on pulmonary function in man: An experimental study. J Clinical Investig 1960, 39:573-583.

44. Cline CC, Coast JR, Arnall DA: A chest wall restrictor to study effects on pulmonary function and exercise. I. Develpment and validation. Respiration 1999, 66:182-187.

45. Weiss HR: The effect of an exercise program on vital capacity and rib mobility in patients with IS. Spine 1991, 16:88-93.

46. Collis DK, Ponseti IV: Long-term followup of patients with idiopathic scoliosis not treated surgically. J Bone Jt Surg 1969, 5 I A:425-445

47. Weinstein SL, Dolan LA, Spratt KF, et al:: Health and function of patients with untreated IS: A 50-year natural history survey. JAMA 2003, 298:559-567.

48. LaPier TK: Chest wall expansion values in supine and standing across the adult lifespan. Phys Occup Ther Geriatrics 2002, 2 I:65-8I.

49. Ascani E, Bartolozzi P, Logroscino CA, Marchetti PG, Ponte A, Savini $R$, Travaglini F, Binazzi F, Di Silvestre $M$ : Natural history of untreated IS after skeletal maturity. Spine 1986, I I:784-789.

50. Bjerkreim R, Hassan I: Progression in untreated IS after the end of growth. Acta orthop scand 1982, 53:897-900.

51. Korovessis P, Piperos G, Sidiropoulos P, Dimas A: Adult idiopathic lumbar scoliosis: a formula for prediction of progression and review of the literature. Spine 1994, 19:1926-1932.

52. Weinstein SL, Ponseti IV: Curve progression in IS. J Bone Jt Surg 1983, 65-A:447-455.

53. Marty-Poumarat C, Scattin L, Marpeau M, Garreau de Loubresse C, Aegerter P: Natural history of progressive adult scoliosis. Spine 2007, I 5: 1227-1234.

54. Perennou DA, Herosson C, Pelissier J: How do scoliotic women shrink throughout life? Eur J Phys Med Rehab 1997, 7:132-137.
55. Hawes MC, Brooks W]: Improved chest expansion in IS after intensive, multiple modality, non-surgical treatment in an adult. Chest 200I, I 20:672-674.

56. Hawes MC, Brooks WJ: Reversal of the signs and symptoms of moderately severe idiopathic scoliosis in response to physical methods. Studies in Health Technol \& Inform 2002, 91:365-368.

57. Hipps HE: The diagnosis of incipient IS. J Bone Jt Surg 1962 , 44:1489.

58. Ponseti IV, Friedman B: Prognosis in IS. J Bone Jt Surg 1950, 32 A:381-395.

59. Moen KY, Nachemson AL: Treatment of scoliosis: an historical perspective. Spine 1999, 24:2570-2575.

60. Brooks W]: Limitations of "symmetry' - introducing "proportionality.". Osteopath Medizin 2009, 9:4-8.

6I. Kappler RE, Jones JM, Kuchera WA: In Diagnosis and Plan for Manual Treatment - A Prescription. Edited by: Ward RC. Foundations for Osteopathic Medicine Williams and Wilkins, Baltimore; 1997:483-8.

62. Bockenhauer SE, Chen H, Julliard KN, Weedon J: Measuring thoracic excursion: reliability of the cloth tape measure technique. J Am Osteopath Assoc 2009, 107:191-196.

63. Lonstein JE: Patient Evaluation. In Moe's Textbook of Scoliosis and Other Spinal Deformities 3rd edition. Edited by: Lonstein J, Bradford D, Winter R, Ogilvie J. Philadelphia: W.B. Saunders; 1995:45-86.

64. Nash CL, Moe JR: A study of vertebral rotation. J Bone Jt Surg 1969, 5 I-A:223-229.

65. Crockett HC, Wright JM, Burke S, Boachie-Adjei O: Idiopathic scoliosis: The clinical value of radiologists' interpretation of preand postoperative radiographs with interobserver and interdisciplinary variability. Spine 1999, 24:2007-20I0.

66. Goldberg MS, Poitras B, Mayo NE, Labelle H, Bourassa R, Cloutier R: Observer variation in assessing spinal curvature and skeletal development in AIS. Spine 1988, I3:137|-|378.

67. Loder RT, Urquhart A, Steen H, Graziano G, Hensinger RN, Schlesinger A, Schork MA, Shyr Y: Variability in Cobb angle measurements in children with congenital scoliosis. J Bone Jt Surg 1995 , 77-B:767-770.

68. Modi HN, Chen T, Suh SW, Mehta S, Srinivasalu S, Yang J, Song H: Observer reliability between juvenile and adolescent idiopathic scoliosis in measurement of stable Cobb angle. Eur Spine J 2009, 1 8:52-58.

69. Ogon M, Giesinger K, Behensky $\mathrm{H}$ : nterobserver and intraobserver reliability of Lenke's new scoliosis classification system. Spine 2002, 27:858-863.

70. Richards BS, Sucato DJ, Konigsberg MD, Ouellet JA: Comparison of reliability between the Lenke and King classification systems for adolescent idiopathic scoliosis using radiographs that were not premeasured. Spine 2003, 28: I | 48-I I 57.

7I. Dickson RA: Spinal deformity--AIS. Nonoperative treatment. Spine 1999, 24:2601-2606.

72. Dickson RA, Weinstein S: Bracing (and screening)--yes or no? Bone Jt Surg 1999, 81-B: 193-198.

73. Taylor JM, Gropper MA: Critical care challenges in orthopedic surgery patients. Crit Care Med 2006, 34:SI9I-SI99.

74. Nachemson A, Bake B, Bjure J, Grimby G, Kaslichy J, Lindh M: Clinical followup and regional lung function studies in patients with nontreated IS. J Bone Jt Surg 1970, 52-A:40 I-408.

75. Pehrsson K, Bake B, Larsson S, Nachemson A: Lung function in adult IS: a 20-year followup. Thorax 199I, 46:473-478.

76. Freidel K, Petermann F, Reichel D, Steiner A, Warschburger P, Weiss HR: Quality of life in women with IS. Spine 2002, 27:E87-E9I.

77. Bengtsson G, Fallstrom K, Jansson B, Nachemson A: A psychological and psychiatric investigation of the adjustment of female scoliosis patients. Acta psychiat scand 1974, 50:50-59.

78. Goldberg MS, Mayo NE, Poitras B, Scott S, Hanley J: The Ste. Justine AIS cohort study: II. Perception of health, self and body image, and participation in physical activities. Spine 1994 , I9:1562-1572.

79. Payne WK, Ogilvie JW, Resnick MD, Kane RL, Transfeldt EE, Blum RW: Does scoliosis have a psychological impact and does gender make a difference? Spine 1997, 22: I 380-I 384.

80. Smith FM, Latchford G, Hall RM, Millner PA, Dickson RA: Indications of disordered eating behaviour in adolescent patients with IS. J Bone Jt Surg 2002, B84:392-394.

81. Hawes MC, O'Brien JP: A century of spine surgery: what can patients expect? Disabil Rehabil 2008, 30:808-8I7. 
82. Lehnert-Schroth C: Introduction to the three-dimensional scoliosis treatment according to Schroth. Physiotherapy 1992, 78:810-8I5.

83. Otman S, Kose N, Yakut Y: The efficacy of Schroth's 3-dimensional exercise therapy in the treatment of AIS in Turkey. Saudi Med J 2005, 26:1429-1435.

84. Rigo M, Quera-Salvá G, Villagrasa M, Ferrer M, Ferrer M, Casas A, Corbella C, Urrutia A, Martínez S, Puigdevall N: Scoliosis intensive out-patient rehabilitation based on Schroth method. Stud Health Technol Inform 2008, 135:208-227.

85. Chen KC, Chiu EH: Adolescent idiopathic scoliosis treated by spinal manipulation: a case study. J Altern Complement Med 2008, |4:749-75|.

86. LeBauer A, Brtalik R, Stowe K: The effect of myofascial release (MFR) on an adult with idiopathic scoliosis. J Bodyw Mov Ther 2008, I 2:356-363.

87. Lewis C, Erhard R, Drysdale G: Kyphoscoliosis improvement while treating a patient for adhesive capsulitis using the active therapeutic movement version 2. J Manipulative Physiol Ther 2008, 31:7I5-722.

88. Maruyama T, Takeshita $K$, Kitagawa $T$ : Side-shift exercise and hitch exercise. Stud Health Technol Inform 2008, 135:246-249.

89. Negrini A, Parzini S, Negrini MG, Romano M, Atanasio S, Zaina F, Negrini S: Adult scoliosis can be reduced through specific SEAS exercises: a case report. Scoliosis 2008, 3:20.

90. Negrini S, Romano M: Axial spinal unloading for adolescent idiopathic scoliosis. Arch Phys Med Rehabil 2007, 88: 1744.

91. Canavan PK, Cahalin L: Integrated physical therapy intervention for a person with pectus excavatum and bilateral shoulder pain: a single-case study. Arch Phys Med Rehabil 2008, 89:2195-2204.

92. Ciazynski D, Czernicki K, Durmala J: Knowledge about idiopathic scoliosis among students of physiotherapy. Stud Health Technol Inform 2008, 140:281-285.

93. Negrini S, Fusco C, Minozzi S, Atanasio S, Zaina F, Romano M: Exercises reduce the progression rate of adolescent idiopathic scoliosis: results of a comprehensive systematic review of the literature. Disabil Rehabil 2008, 30:772-785.

94. Negrini S: Approach to scoliosis changed due to causes other than evidence: patients call for conservative (rehabilitation) experts to join in team orthopedic surgeons. Disabil Rehabil 2008, 30:73|-74I.

95. Romano M, Negrini S: Manual therapy as a conservative treatment for adolescent idiopathic scoliosis: a systematic review. Scoliosis 2008, 3:2.

96. Weiss HR, Goodall D: The treatment of adolescent idiopathic scoliosis (AIS) according to present evidence. A systematic review. Eur J Phys Rehabil Med 2008, 44:177-193.

97. Everett CR, Patel RK: A systematic literature review of nonsurgical treatment in adult scoliosis. Spine 2007, 32:SI30-I34.

98. Negrini S, Antonini G, Carabalona R, Minozzi S: Physical exercises as a treatment for AIS. A systematic review. Ped Rehab 2003, 6:227-236.

99. Gardner-Morse MG, Stokes IA: Physiological axial compressive preloads increase motion segment stiffness, linearity and hysteresis in all six degrees of freedom for small displacements about the neutral posture. J Orthop Res 2003, 21 :547-552.

100. Villemure I, Stokes IA: Growth plate mechanics and mechanobiology. A survey of present understanding. J Biomech 2009, 42:1793-1803.

10I. Grivas TB, Vasiliadis E, Savvidou OD, Triantafyllopoulos G: What a school screening program could contribute in clinical research of idiopathic scoliosis aetiology. Disabil Rehabil 2008, 30:752-762.
Publish with Bio Med Central and every scientist can read your work free of charge

"BioMed Central will be the most significant development for disseminating the results of biomedical research in our lifetime. "

Sir Paul Nurse, Cancer Research UK

Your research papers will be:

- available free of charge to the entire biomedical community

- peer reviewed and published immediately upon acceptance

- cited in PubMed and archived on PubMed Central

- yours - you keep the copyright
BioMedcentral 